MARIJA UNTERBERGER, Ph.D. ${ }^{1}$

E-mail: marijaunterberger@gmail.com

PREDRAG VEŠOVIć, M.Sc. ${ }^{2}$

E-mail vesovic.pedja@gmail.com

KATARINA MOSTARAC, Ph.D. ${ }^{3}$

(Corresponding author)

E-mail: kmostarac@fpz.hr

DRAGANA ŠARAC, Ph.D. ${ }^{4}$

E-mail: dsarac@uns.ac.rs

SPASENIJA OŽEGOVIĆ, Ph.D. ${ }^{5}$

E-mail: sozegovic@ptt.rs

${ }^{1}$ Traffic school „Pinki“ of Novi Sad

Šumadijska 12a, 21000 Novi Sad, Serbia

2 TRANS LOGISTICS AG, International transport \& spedition

Bul. Arsenija Čarnojevića 130, 11070 New Belgrade,

Serbia

3 University of Zagreb

Faculty of Transport and Traffic Sciences

Vukelićeva 4, 10000 Zagreb, Croatia

${ }^{4}$ University of Novi Sad, Faculty of Technical Sciences

Trg Dositeja Obradovića 6, 21000 Novi Sad

${ }^{5}$ Faculty of Applied Sciences Management, Economics and

Finance Belgrade, University Economic Academy

of Novi Sad, Jevrejska 24, 11000 Belgrade, Serbia
Traffic Policy

Review

Submitted: 5 Oct. 2017

Accepted: 5 Feb. 2018

\title{
THREE-DIMENSIONAL CORPORATE SOCIAL RESPONSIBILITY MODEL OF A POSTAL SERVICE PROVIDER
}

\begin{abstract}
In this paper, the term "corporate social responsibility" (CSR) was first observed based on the existing pyramid, which defines CSR as a set of economic, legal, ethical, and philanthropic activities. Then the dimensioning of the model of corporate responsibility in postal system was performed, where seven categories of the CSR model were defined. Only one category (out of seven) represents a set of all four activities defined by the existing pyramid. Based on this, a new model of CSR in the postal system was developed, that is seen through the development of three dimensions of the postal network: physical $(P H)$, electronic $(E)$, and financial (F). The main objective of the paper is to define a CSR model that will ensure the economic, social, and environmental development of the postal market by synergistic operation of all three dimensions of the postal network. An analysis of the existing state of the postal services market was carried out, and then the level of the future development of the postal network was determined. Through evaluation or systematic and objective assessment of the CSR model based on the determined parameters, measurability of the CSR model is assured. This paper deals with the case of the public postal operator (PPO) in the Republic of Serbia (RS).
\end{abstract}

\section{KEYWORDS}

corporate social responsibility; postal network; evaluation; synergy; postal market;

\section{INTRODUCTION}

\subsection{Theoretical background of corporate social responsibility}

Corporate social responsibility (CSR) is a concept that emerged in the 1950s in the United States, as a field of study in economics. According to the European Commission, it is defined as "the concept by which the company integrates care for society and the environment in its business activities and interaction with its stakeholders on a voluntary basis" [1]. According to Hopkins [2], socially responsible operation is defined as "the attention with which we relate in an ethical and socially responsible manner to interest-bearing groups that are located out of organization, but also within the organization." Despite numerous efforts to provide a clear and unambiguous definition of socially responsible operation, there is still some confusion over its definition. In a book written by Dahlsrud, a general definition is proposed, whereby "socially responsible operation refers to the responsibilities of the company and to the undertaking of measures within companies that exceed their legal obligations and economic/business objectives, while emphasizing three main objectives: economic, social, and environmental" [3]. 
The international standard ISO 26000 provides guidelines and directions on social responsibility [4]. The goal of the ISO 26000 standards is to help organizations in their efforts to act in a socially responsible way and to help them contribute to sustainable development.

According to [5], the social responsibility of a business encompasses the economic, legal, ethical, and philanthropic categories, presented through the four-level pyramid of CSR (Figure 1).

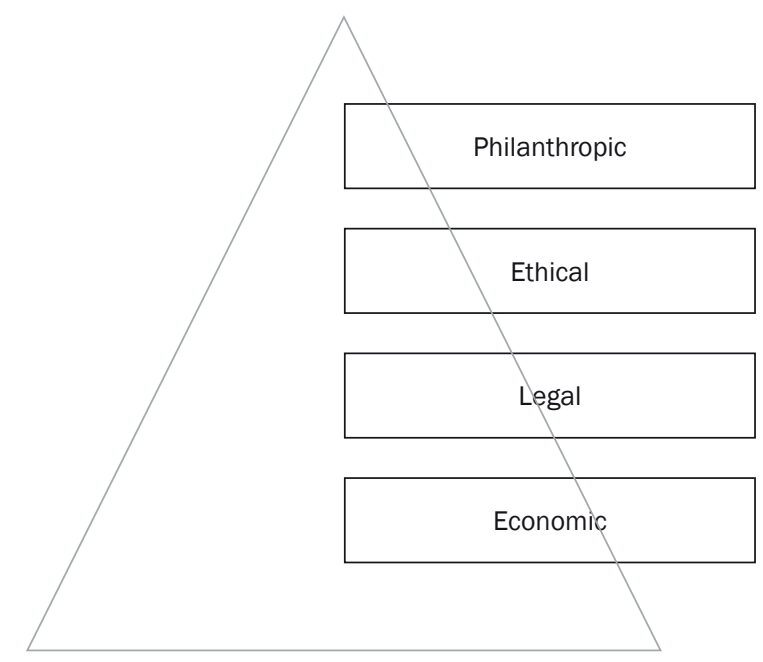

Figure 1 - The corporate social responsibility pyramid [5]

CSR is presented through four levels of hierarchy. The sets of economic responsibilities (to be profitable), legal responsibilities (compliance with general legal regulations, laws on ecology, consumer protection, employee protection, anti-corruption laws, etc.), and ethical responsibilities (to be honest and behave according to the generally accepted moral principles of society) are the bases for the philanthropic liability of a public postal operator (PPO). Aspects of such operation are numerous and reflect in the philanthropic activity of the company in support of the socio-cultural and economic development of the community, environmental protection programs, and environmentally friendly products, processes, and technologies.

According to [6], measuring and quantifying CSR is to remain a challenge. This paper proposes a new three-dimensional model aiming to measure the CSR of a postal operator by applying an adjusted CSR pyramid (as shown in Figure 3). This three-dimensional CSR model (Figure 4) will enable the distinction of PPOs from competitors and will ensure their better positioning on the market. By a long-term synergy of the physical, electronic, and financial networks, the economic development of the postal market will be ensured (through reducing the costs of business and increasing profits), social development (through better cooperation with the local community, cooperation with postal operators), and a positive impact on living standard (due to the synergistic effect of all three dimensions of the postal network that will contribute to reducing harmful exhaust gases and better utilization of existing resources). The developed model serves to measure the CSR of any PPO and is based on the quantified values of all three dimensions of the postal network.

\subsection{Examples of application of CSR in postal sector}

There are numerous examples of activities that postal operators carry out in promoting CSR. Through its Corporate Social Responsibility Strategy, the Post Office of the United Kingdom provides a secure and sustainable universal postal platform through the development of physical networks by supplying postal services. It is present in every region of the UK, where it employs locals and connects with its customers, companies, and communities. It nurtures its employees through various programs of education and training. In addition to employees, it takes care of its customers, and because of that it introduced a regular line of a "Post Bus", which, in addition to goods, transports passengers, i.e., elderly people with special needs.

To highlight the concern of the older population in Great Britain, the paper [7] presents an analysis of the distance of the older population from postal network units using the GIS tools. CSR is present in solving the problem of social inclusion by using the postal network to ensure the development of a financial network to provide various services for the socially vulnerable population [8].

In France, "La Poste" has focused on strengthening the physical post network in remote urban environments, focusing on hiring young people from poorer areas. It is possible to organize other activities in the post offices through partnerships with local organizations, which is of great importance for the elderly or socially vulnerable population [9].

According to Lee, [10] mathematical modeling is formulated to define the optimal number of postal units of "Post Korea" with the aim of reducing costs. In this way, the optimal physical availability of the postal network is ensured in order to rationalize all available resources.

\section{APPLICATION OF CSR CONCEPT TO POSTAL SYSTEM}

\subsection{Strategic background}

Strategic planning of CSR is a management philosophy that infuses a company [6]. Therefore, it is essential to incorporate strategic determinants when planning the corporate responsibility of a company. 
The strategic determinants of a postal service provider in this paper are adopted according to the UPU (Universal Postal Union) Doha Congress Strategy. Table 1 shows the basic goals and the most important conclusions of the $25^{\text {th }}$ UPU Congress held in Doha in 2012, which should ensure the continued development of efficient and affordable universal postal services [12].

The defined goals, through the development of physical, electronic, and financial networks, should provide [12]:

- Free flow of postal items through a single postal territory;

- Adoption of uniform standards that will ensure cooperation and interaction between the public and private sectors through efficient technical cooperation; and

- Satisfaction of the different contemporary needs of postal service users.

All of the previously defined goals will contribute to the improvement of communication between the world population (interconnection), the development of the entire postal network, and better management and organization within the postal system. The development of the physical network implies the optimal number of postal network units as well as the necessary resources to ensure access to postal networks and their availability in rural areas. The electronic network is a communication network for the provision of electronic postal services (e-mail, e-finance, e-government, and e-commerce). The financial network is a network for the development of financial services provided by the PPO, which should provide public-private partnerships with the aim of involving all users, especially the socially vulnerable population.

\subsection{Dimensions of the corporate responsibility in postal system}

Inspired by the idea of the three-domain CSR model (economic, legal, ethical) [13], a four-domain CSR model for postal systems is proposed, showing domains defined by the CSR pyramid, with an emphasis on the development of physical, electronic, and financial networks. In Figure 2, seven categories of CSR models are depicted depending on the development of the domains.

Postal operators first develop (I), a physical network $(\mathrm{Ph})$, based on the economic and legal principles (the number of postal network units required to provide UPS and an optimal number of units to reduce fixed costs). Only with the development of the physical network do they tend to develop (II), an electronic network $(E)$, and then (III), a financial network (F), also based on the economic and legal principles. These first three categories will enable: the optimal number of postal network units required to provide UPS; access to the postal network; and provision of defined electronic and financial services. Only the development of the economic and legal domains creates space for the development of the ethical domain and the following three categories of CSR models - (IV), (V), and (VI). The synergy of the economic, legal, and ethical domains

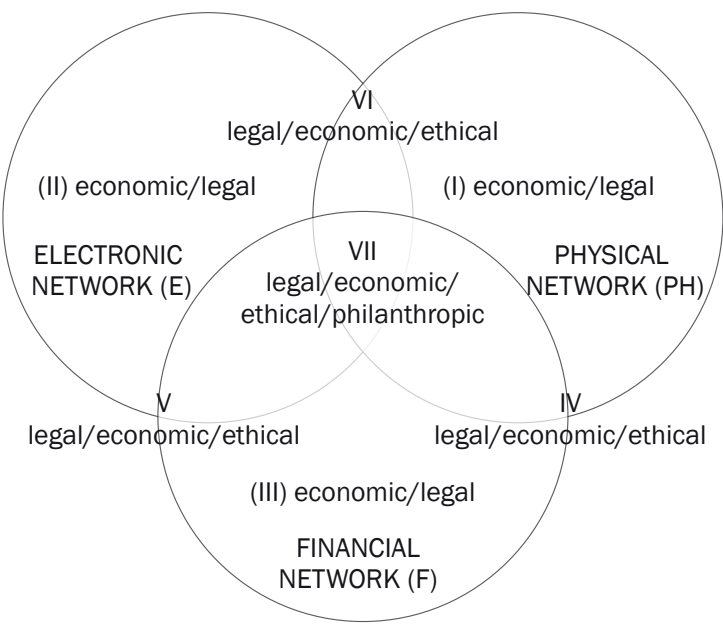

Figure 2 - Postal system CSR models viewed through all four CSR pyramid domains (adjusted according to [13])

Table 1 - The most important goals and directions of development of the Doha Strategy (adjusted according to [12])

\begin{tabular}{|c|c|c|c|c|c|}
\hline \multicolumn{2}{|l|}{ Interconnection } & \multicolumn{2}{|c|}{ Development } & \multicolumn{2}{|r|}{ Governance } \\
\hline GOAL 1 & \multicolumn{2}{|r|}{ GOAL 2} & \multicolumn{2}{|c|}{ GOAL 3} & GOAL 4 \\
\hline $\begin{array}{l}\text { Improve the interoperability of the } \\
\text { international postal networks }\end{array}$ & \multicolumn{2}{|c|}{$\begin{array}{l}\text { Provide technical } \\
\text { knowledge and expertise } \\
\text { related to the postal } \\
\text { sector }\end{array}$} & \multicolumn{2}{|c|}{$\begin{array}{c}\text { Promote innovative } \\
\text { products and services } \\
\text { (developing the 3-D } \\
\text { network) }\end{array}$} & $\begin{array}{c}\text { Foster sustainable } \\
\text { development of the postal } \\
\text { sector }\end{array}$ \\
\hline \multicolumn{2}{|l|}{ PHYSICAL network } & \multicolumn{2}{|c|}{ ELECTRONIC network } & \multicolumn{2}{|c|}{ FINANCIAL network } \\
\hline \multicolumn{2}{|c|}{$\begin{array}{c}\text { Determining the optimal number of postal } \\
\text { network units }\end{array}$} & \multicolumn{2}{|c|}{ E-post office } & \multicolumn{2}{|c|}{ Financial inclusion } \\
\hline \multirow{2}{*}{\multicolumn{2}{|c|}{ Access to the PPO postal network }} & \multicolumn{2}{|c|}{ E-finance } & \multicolumn{2}{|c|}{$\begin{array}{l}\text { Providing universal financial service / } \\
\text { scope of universal postal service (UPS) }\end{array}$} \\
\hline & & \multicolumn{2}{|c|}{ E-government } & \multirow{2}{*}{\multicolumn{2}{|c|}{$\begin{array}{l}\text { Public-private partnerships in providing } \\
\text { financial services }\end{array}$}} \\
\hline \multicolumn{2}{|c|}{ Availability of postal network in rural areas } & \multicolumn{2}{|c|}{ E-commerce } & & \\
\hline
\end{tabular}


will enable the availability of the postal network and universal postal services and the financial inclusion of the population. By synergizing all three previous domains through all three networks, a space for the philanthropic domain and the definition of (VII) of the CSR model is developed.

According to [5], the CSR pyramid defines four levels of corporate responsibility: economic, legal, ethical, and philanthropic. Analogously, it is possible to consider the CSR pyramid for a postal system, where the complexity of the system is observed, including a large number of participants and a high degree of interdependence between processes and activities. By applying the CSR concept to the postal system, it is possible to identify a greater number of hierarchical levels in the provision of postal services from the aspect of the development of three dimensions of the postal system: physical (Ph), electronic (E), and financial (F) (Figure 3).

In accordance with the above mentioned, the main goal of this paper is to study the dimensions of CSR and to propose a model for measuring CSR in the postal system, which should provide:

- customer care (through increasing the availability of postal networks, involving various social and economic groups of users);

- care for the environment by reducing the harmful effects of carbon dioxide emissions and other harmful exhaust gases;

- better utilization of the existing resources of the postal network, local community, and business environment to achieve energy efficiency and reduce energy consumption;

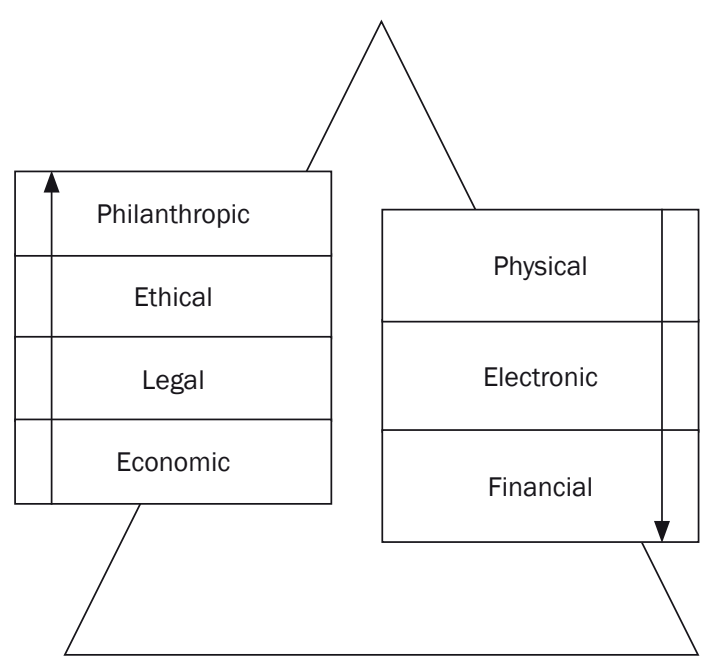

Figure 3 - CSR pyramid of a three-dimensional postal system

(adjusted according to [14])

- building and putting into operation a unique public postal-logistic and communication network.

\section{A NEW MODEL OF CORPORATE SOCIAL RESPONSIBILITY IN THE POSTAL SYSTEM}

To formulate the CSR model in the postal system, the following methodology is suggested:

1) Analysing the existing state of the postal services market to determine the market share of postal operators according to types of services, scope, and value of the work performed;

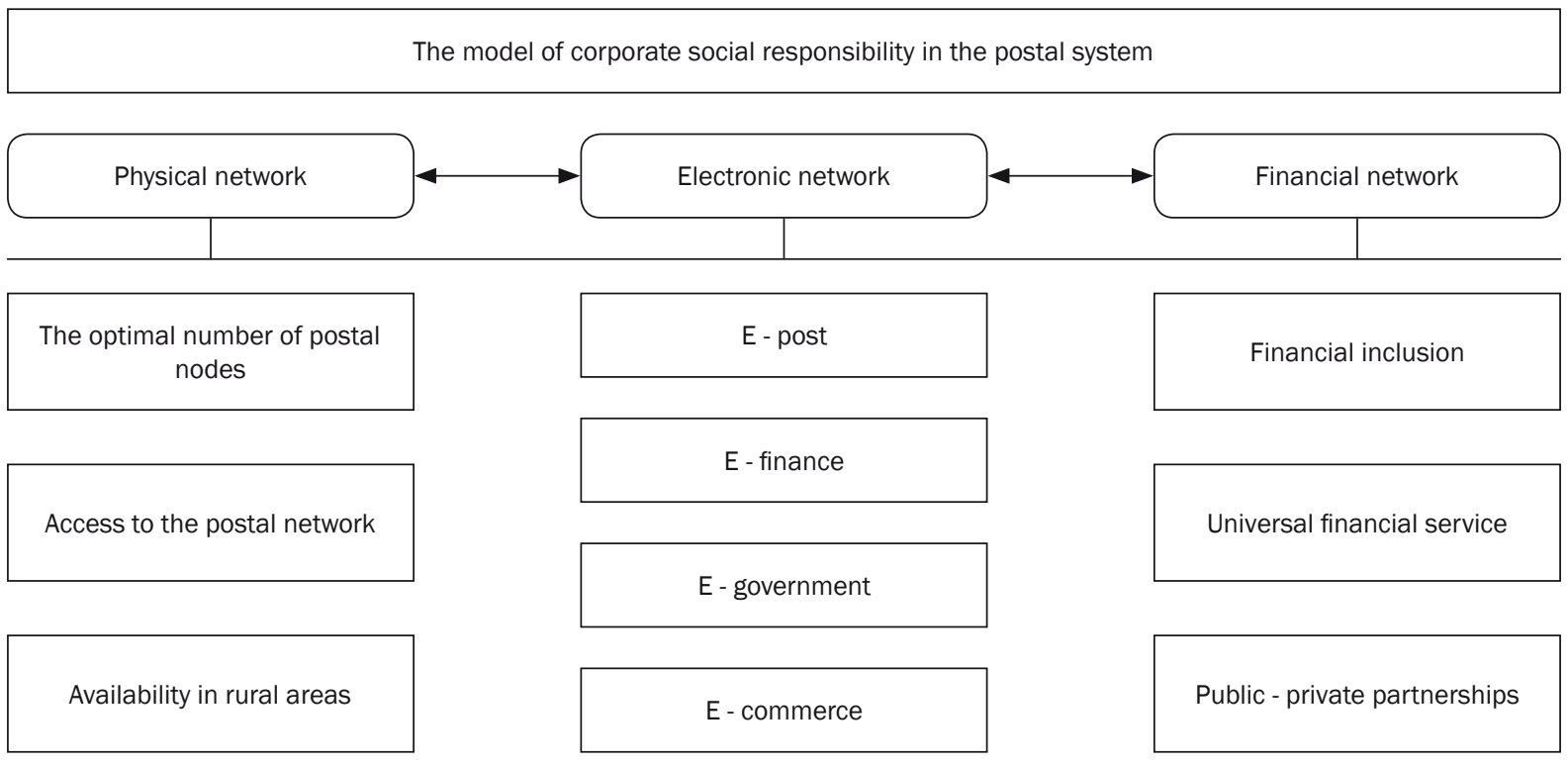

Figure 4 - Three-dimensional model of corporate social responsibility in postal system 
2) Determining the optimal level of the future development of the postal network in terms of the physical, financial, and electronic accessibility of postal operators' services, with the aim of providing CSR;

3) Evaluating the proposed CSR model of the postal system.

A new model of postal system CSR is proposed, which should ensure the synergy of all three dimensions (as shown in Figure 4). Since it is difficult to measure the corporate responsibility of a company, the focus of this paper is to analyze the three dimensions of the postal network and to present measurable results of all three dimensions that make up the overall CSR model of the postal system.

The basic assumptions of the model are:

- The optimum level of development of the physical network can be achieved by determining the optimal number of postal nodes and the implementation of access to the postal network, to ensure accessibility in rural areas.

- Electronic network development level needs to be further increased through existing electronic resources available to PPOs to define e-post, e-finance, e-government, and e-commerce.

- Financial network development can be achieved through financial inclusion and public-private partnerships and the inclusion of financial services in the scope of universal postal services.

\section{APPLICATION OF THE PROPOSED MODEL - A CASE STUDY OF SERBIA}

During 2016, the Post of Serbia, as the public postal operator, placed emphasis on providing a better access to the postal network for all its users through two major projects. The first project " 52 Post Offices in 52 Weeks" included opening 52 new post offices, where access to additional and not only universal postal services for postal network users was enabled and facilitated, both in places where the post offices were opened and in the surrounding areas. The second project, "Postman as a Mobile Counter", is aimed not only to facilitate citizens' access to the postal network but also to facilitate access to healthcare and municipal officials. Namely, the aim of the project is that the crew of a special-purpose vehicle is made up of municipal officials, such as doctors and postal workers. According to a predetermined plan, the vehicle would be in certain places, and citizens could use the services without traveling significant distances, which would result in major savings of transport costs, as well as the time needed to perform the above-mentioned tasks.

In addition, following the trends of other postal administrations, as well as taking responsibility for the environmental protection, the Post of Serbia has started to introduce electrically powered vehicles. Electrical bicycles and mopeds are being introduced, and the procurement and testing of electric vehicles is planned. They will replace vehicles with internal combustion engines and eliminate emissions of harmful exhaust gases in the future. Until all the conditions for all vehicles to be electrically driven are met, any procured transport vehicles with internal combustion engines (trucks, vans, passenger cars, and mopeds) must be of the latest generation, and the amount of exhaust gases must meet the highest environmental standards (EUR 5 and EUR 6).

During 2016, the range of new services performed by PPOs for the development of the financial and electronic networks significantly increased. Exchange counters in post offices and international money transfers (by postal reference) were introduced for France, Russia, Ukraine, Belarus, Montenegro, Bosnia and Herzegovina, and Croatia. To facilitate e-commerce in Serbia for natural and legal persons (state administration, local self-government, public services, enterprises, banks, insurance companies, organizations, institutions), the Post Certification Authority was established. Electronic (digital) certificates are intended for all participants in Serbia's electronic commerce. In 2016, PPO started the implementation of insurance brokerage services in customer service units.

However, in 2016, postal service users' opinions on the CSR activities of the universal postal service operator in the Republic of Serbia were analyzed in the paper [14]. On the scale from 1 to 5, natural persons rated them with 3.16 , and legal entities rated them with 3.00. It can be concluded that there is significant room for improving the CSR activities of Serbia's PPO.

\subsection{Analysis of the current situation in the postal services market}

The postal sector in Serbia represents a significant economic segment, as it makes up to $1 \%$ of the total GNP (Gross National Product). Universal postal service in the country is provided only by the Post of Serbia. The remaining 57 postal operators provide only non-universal postal services. In the field of postal services, the legislation in the Republic of Serbia is harmonized with the Directives 1997/67/EC [11] and 2002/39/EC [15], and to a certain extent with the Directive 2008/6/EC [16]. Complete liberalization of the postal market has not been achieved yet because there is a monopoly on the market in the field of reserved postal services (letters up to $100 \mathrm{~g}$ of weight, court letters, postal and electronic referral).

Figure 5 shows the volume of postal services of the Post of Serbia. It is evident that the majority of services are letter post services (59\%), followed by financial services (32\%).

However, observing the revenues from these services, $45 \%$ come from financial services, while 39\% pertain to postal services. In the structure of revenues, 


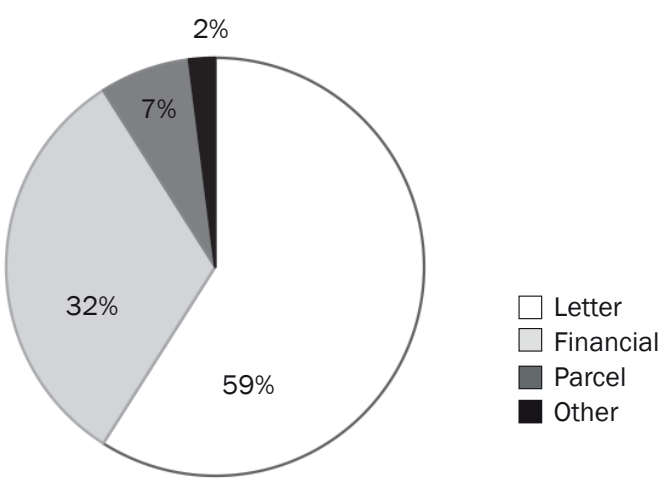

Figure 5 - Volume of postal services of the Post of Serbia

the PPO's dominant share of income is generated by business users. Particularly important is the segment of a small number of business users that have a huge impact on the revenues and scope of postal services. According to [17], about $5 \%$ of users generate approximately $79 \%$ of Post of Serbia revenues.

\subsection{The optimal level of future development of the postal network}

According to [18], several hundred million people in the world who do not have bank accounts use the postal network for basic services, payments, money transfers, and orders in domestic and international money transactions. Provision of financial services by post contributes to active involvement of socially and economically disadvantaged population in the financial sector. In this way, adverse social phenomena are prevented, and experience has shown that postal organizations are optimal providers of affordable financial services, which serves to protect and ensure the sustainability of the postal network [19]. Financial services combined with universal postal service and public postal network can integrate postal providers into the global fight against financial exclusion. To achieve sustainable financial inclusion, it is important to meet the needs and expectations of several entities: financial service users, financial service providers in the country, and the entire society [20].

To ensure the optimal level of development of the postal network, it is necessary to define the optimal number of postal network units and the density of access points in accordance with the needs of users (natural persons, legal entities, and postal operators). It is necessary to determine the minimum number of permanent post units in the Republic of Serbia and to determine the conditions of access for postal operators, consolidators, and other users.

According to [21], electronic postal services are classified into four categories: e-post, e-commerce, e-finance, and e-government. A total of 55 electronic services have been recorded (29 e-post services, 9 e-finance, 6 e-commerce, and 11 e-government services), although practice often shows that one postal electronic service may combine two or more of the above four categories.

\section{The development of the physical network (Ph)}

In this paper, the development of the physical dimension of the postal network is analyzed through several measurable aspects:

- optimization of the public postal network [22];

- analysis of the accessibility of universal service in the postal system using the criteria of transport connectivity [23]; and

- the definition of optimal points for the access of postal operators to the public postal network [24].

The research carried out in the paper [22] determined the minimal number of postal units by applying the set covering location problem, using air distances in an urban area. In [23], a model was developed for determining the accessibility of universal service by using the criteria of transport connectivity, which implies acceptable travel times for postal service users in rural areas. The paper [25] presents reorganization of parcel services between postal logistics centers and post offices by adding regional parcel centers and parcel posts to the network. The obtained results of optimal network structure indicate the reduction of the total transportation distances by $32 \%$, while transport costs are reduced by $20 \%$.

The study conducted in the paper [24] defines the optimal points of access of postal operators to the public postal network and points out the need for complete liberalization of the market (the abolition of the reserved area). In the scenario of complete liberalization, the results showed that the optimal points would be in the starting (upstream) and the destination (downstream) regional and local postal logistic centers in the territory of the Republic of Serbia. Access would be possible at 16 access points, with discounts and total amounts of letters and packages, as shown in Table 2.

The development of the electronic network $(E)$

The development of the electronic network is considered through measurement and application of the index of postal e-services development (PES index).

In the Post of Serbia, the following e-post services are recognized: web information about services and their prices, hybrid mail, finding postal code, locating post office location, track and trace, web based customer service and contact, electronic notification to the recipient about sending the letter, electronic notification to the sender that the letter has been delivered, electronic notification to the recipient of the package to be delivered, electronic notification that the package has been delivered; e-finance services: 
Unterberger M, Vešović P, Mostarac K, Šarac D, Ožegović S. Three-dimensional Corporate Social Responsibility Model of a Postal Service...

Table 2 - Results of defining the basic conditions for access to the postal network [25]

\begin{tabular}{||l|c|c|c|c||}
\hline \multirow{2}{*}{\multicolumn{1}{|c|}{ Points of access }} & \multicolumn{2}{|c|}{ Discount } & \multicolumn{2}{c|}{$\begin{array}{c}\text { The total amount of } \\
\text { (on monthly basis) }\end{array}$} \\
\cline { 2 - 5 } & Letters & Packages & Letters & Packages \\
\hline \hline RPLC - (Upstream) & $11.33 \%$ & $10 \%$ & 20,000 & 17,021 \\
\hline $\begin{array}{l}\text { RPLC - (Downstream) } \\
\text { LPLC - (Downstream) }\end{array}$ & $27.19 \%$ & $36.94 \%$ & 77,436 & 46,216 \\
\hline
\end{tabular}

Table 3 - PES index obtained by using Minitab

\begin{tabular}{|c|c|c|c|c|c|c|c|c|}
\hline No. & Country & PES index & No. & Country & PES index & No. & Country & PES index \\
\hline 1 & Switzerland & 4.525985366 & 34 & $\begin{array}{l}\text { United Arab } \\
\text { Emirates }\end{array}$ & 0.225662486 & 67 & $\begin{array}{l}\text { Saint Kitts } \\
\text { and Nevis }\end{array}$ & -1.0211917 \\
\hline 2 & Belarus & 4.230172466 & 35 & Lithuania & 0.075920971 & 68 & Pakistan & -1.034168 \\
\hline 3 & Germany & 3.260980489 & 36 & Egypt & -0.080799316 & 69 & Madagascar & -1.0523328 \\
\hline 4 & Qatar & 3.106770566 & 37 & Serbia & -0.184378431 & 70 & Gibraltar & -1.1084282 \\
\hline 5 & Italy & 3.083792395 & 38 & Cyprus & -0.293475817 & 71 & Zimbabwe & -1.1644464 \\
\hline 6 & Denmark & 3.074806874 & 39 & Mongolia & -0.321876356 & 72 & Guinea & -1.2061546 \\
\hline 7 & Tunisia & 2.613057751 & 40 & Poland & -0.327077495 & 73 & Cameroon & -1.2137606 \\
\hline 8 & Canada & 2.528910602 & 41 & Mauritius & -0.332455723 & 74 & Rwanda & -1.2164802 \\
\hline 9 & France & 2.380430642 & 42 & Mozambique & -0.358276921 & 75 & Philippines & -1.2799067 \\
\hline 10 & Austria & 2.356666422 & 43 & Sri Lanka & -0.360185548 & 76 & Uruguay & -1.2827382 \\
\hline 11 & $\begin{array}{l}\text { United } \\
\text { States }\end{array}$ & 2.334188529 & 44 & Uzbekistan & -0.45052891 & 77 & El Salvador & -1.3016055 \\
\hline 12 & Australia & 2.113366621 & 45 & Bulgaria & -0.46493602 & 78 & $\begin{array}{l}\text { Papua New } \\
\text { Guinea }\end{array}$ & -1.3771132 \\
\hline 13 & $\begin{array}{l}\text { Republic of } \\
\text { Korea }\end{array}$ & 2.030940875 & 46 & $\begin{array}{l}\text { Bosnia and } \\
\text { Herzegovina }\end{array}$ & -0.476457685 & 79 & Mali & -1.3798327 \\
\hline 14 & Portugal & 1.933247869 & 47 & Maldives & -0.482335941 & 80 & Comoros & -1.3800906 \\
\hline 15 & Singapore & 1.831566952 & 48 & Mexico & -0.5055939 & 81 & Bolivia & -1.4156967 \\
\hline 16 & Spain & 1.381071528 & 49 & Nepal & -0.5197727 & 82 & Tajikistan & -1.4287657 \\
\hline 17 & Slovakia & 1.372612135 & 50 & Malta & -0.5835762 & 83 & Ghana & -1.4287657 \\
\hline 18 & Saudi Arabia & 1.313334144 & 51 & Guatemala & -0.602075 & 84 & Lao & -1.4287657 \\
\hline 19 & China & 1.117832693 & 52 & Iran & -0.6192882 & 85 & Netherlands & -1.4516578 \\
\hline 20 & Israel & 1.105180376 & 53 & Djibouti & -0.6535846 & 86 & Dominica & -1.4649581 \\
\hline 21 & South Africa & 1.09255576 & 54 & Lebanon & -0.6557004 & 87 & Ecuador & -1.4649581 \\
\hline 22 & Greece & 0.979631309 & 55 & Namibia & -0.6727653 & 88 & Panama & -1.4649581 \\
\hline 23 & Brazil & 0.941886525 & 56 & Myanmar & -0.7685382 & 89 & Iraq & -1.5496421 \\
\hline 24 & Hungary & 0.926936051 & 57 & Argentina & -0.7995971 & 90 & $\begin{array}{l}\text { Syrian Arab } \\
\text { Republic }\end{array}$ & -1.5496421 \\
\hline 25 & Thailand & 0.867670344 & 58 & Chad & -0.8047191 & 91 & Turkmenistan & -1.5496421 \\
\hline 26 & Costa Rica & 0.771535674 & 59 & Kuwait & -0.8231361 & 92 & $\begin{array}{l}\text { Sao Tome and } \\
\text { Principe }\end{array}$ & -1.5496421 \\
\hline 27 & Turkey & 0.584174149 & 60 & Nigeria & -0.8655126 & 93 & Tonga & -1.5496421 \\
\hline 28 & $\begin{array}{l}\text { United } \\
\text { Kingdom }\end{array}$ & 0.574300601 & 61 & Malawi & -0.9441545 & 94 & Angola & -1.5523617 \\
\hline 29 & Kenya & 0.565038685 & 62 & Tanzania & -0.9955277 & & & \\
\hline 30 & Ukraine & 0.418203546 & 63 & Gambia & -1.0123511 & & & \\
\hline 31 & Jordan & 0.409220355 & 64 & Bhutan & -1.0165731 & & & \\
\hline 32 & Kyrgyzstan & 0.401617834 & 65 & Botswana & -1.0165966 & & & \\
\hline 33 & $\begin{array}{l}\text { Russian } \\
\text { Federation }\end{array}$ & 0.348373648 & 66 & Burkina & -1.0184494 & & & \\
\hline
\end{tabular}


electronic money transfer; e-commerce: SSL web certificates; and e-governor: digital identity, electronic source of documents, electronic customs documents.

By calculating the PES index, conclusions about the development level of electronic services of the Republic of Serbia were made based on the development of electronic services provided at the Post of Serbia. The analysis included 94 SPS countries, whereby data processing was done using the Minitab software package. First, a PCA (principal component analysis) was conducted by analyzing the index for the postal service, then for financial and commercial electronic services, and, finally, a single index was obtained through PCA. It was necessary to conduct a survey and calculate the PES index to make the appropriate conclusions about the status of Serbia in terms of electronic services provided as part of the postal service. It should be noted that all variables used in the construction of the main indexes (e-mail, e-finance, e-commerce) have a discrete binary nature, or the variable is encoded in such a way that 1 indicates that the service is available, and 0 indicates that the service is not available.

The results of this processing in Table 3 show that Serbia ranks $37^{\text {th }}$, with the PES index of -0.18 [26]. This result should be considered acceptable, since it puts Serbia ahead of some economically developed countries. However, for future operation, it is advisable to consult, for example, the PPOs of Switzerland and Belarus, the countries have the most developed programs of electronic services.

The PES index will help the postal system of Serbia orientate in terms of its electronic operations and provide insight into the real state of the electronic services.

The results have shown that further development of electronic commerce also requires improvements to the telecommunication infrastructure, as there is dependence between the PES index and the development of telecommunication infrastructure (Figure 6a).

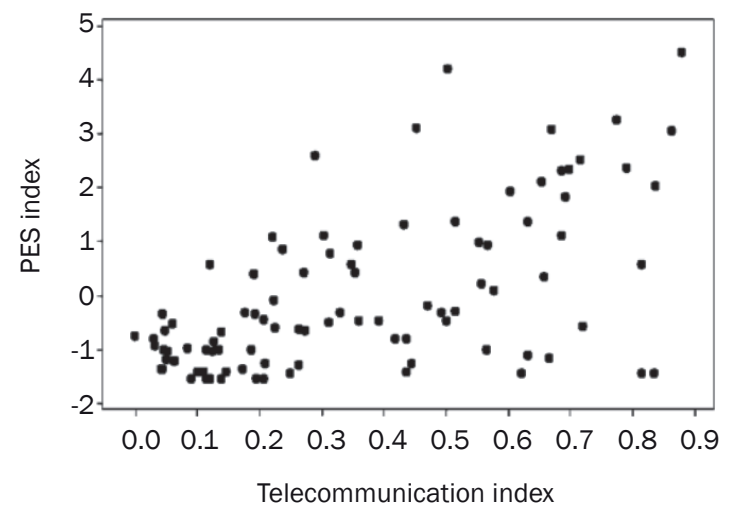

a) PES index and telecommunication index
A higher level of economic development is usually associated with higher demand for service provision. Figure $6 b$ shows a "scatter plot" that reveals the link between the PES index and the level of economic development of the country. It also shows that some countries with a relatively low GNP, such as Belarus and Tunisia, have a very good PES index. Other countries, such as Great Britain and Cyprus, with a very high GNP, have not conducted diversification and reform of their postal companies, and their PES indexes are below the predicted values.

The calculated PES index represents the core system for designing the dynamics and goals towards the development of electronic operations as well as for the examination of the optimal level of development of the electronic network in Serbia. The results of the calculation of the dependence between the development of telecommunication infrastructure and postal e-services indicate the expected positive linear relationship between these two parameters, which contributes to the significance of the impact of this dimension on the development of CSR.

\section{The development of the financial network $(F)$}

According to data from 2017, there are 31 operating banks in Serbia, which are mostly foreign-owned. To determine ways to ensure the optimal level of development of the financial network, a survey among 1350 users of financial services in Serbia was conducted [27], stating some of the basic problems when using these services:

- the banks' working hours are inadequate;

- banks do not have branches in their places of residence;

- insufficient information on the services provided by the banks;

- poor financial situation and high commissions and interest rates.

In terms of the most commonly used financial services, the results show the following:

- $98 \%$ of the respondents own bank accounts;

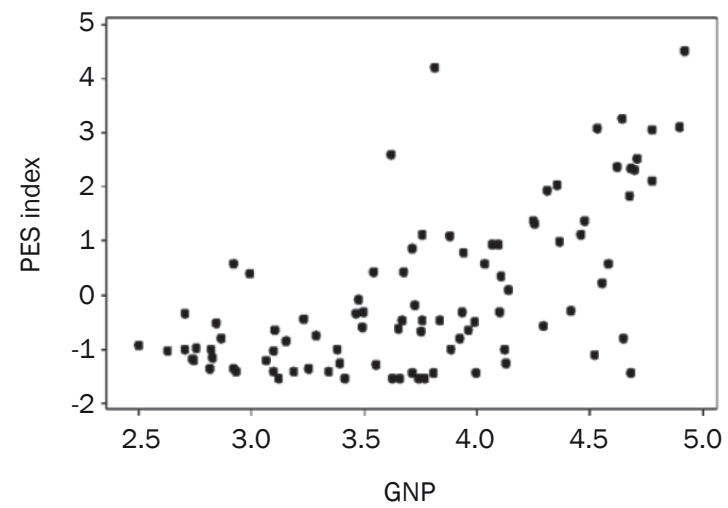

b) PES index and GNP

Figure 6 - Scatter plots [26] 
- $67 \%$ of the respondents use debit payment cards, while $15 \%$ of the respondents use credit cards and $22 \%$ of the respondents use some form of credit;

- $63 \%$ of the respondents use postal finance services for payment of utility bills, others use banks' services or pay bills by standing orders.

The basic resources available to the PPO regarding the development of the financial infrastructure, on which CSR will continue to be based, include the following:

- developed ICT solutions (computer network PosTis, post office certification body, Center for Post of Serbia e-Business (CePP) as a multimedia service provider, GIS services);

- various e-government projects in the Republic of Serbia (for example, electronic data exchange about citizens and establishing electronic records on Serbian citizens for the needs of the Ministry of Internal Affairs and the Ministry of Public Administration and Local Self-Government);

- postal network with about 1,500 locations in Serbia (with around 4,000 payment gateways);

- contractual relations with banks, utilities, and other organizations and institutions.

To develop a financial network in Serbia which will ensure the synergy of existing resources and contribute to the development of the CSR model, it is necessary to improve the quality of existing financial services, customer relations, and ensure the introduction of new services such as:

- services for profiling beneficiaries of affordable financial services based on an already existing e-government service, to reduce the costs of obtaining the necessary documentation,

- services for socially vulnerable and low-income population in the form of interest-free loans or loans at a lower interest rate,

- insurance services, primarily health and pension, with the possibility of providing savings.

\subsection{Evaluation of the proposed model}

The CSR model in Serbia's postal system is observed through the physical, electronic, and financial dimensions and the synergy of the economic, legal, ethical, and philanthropic domains (shown in Figure 2 through VII). To carry out the evaluation of VII, it is first necessary to define the parameters according to which systematic and objective assessment of the model will be carried out. The system parameters can be:

For a physical network (Ph):

a) Number of postal network units (PNU);

b) Number of access points to the PPO postal network;

c) Number of households for which certain services are available.

For an electronic network (E): a) Calculated PES index, obtained based on the number of provided electronic services in relation to the total number of defined electronic services.

For a financial network $(F)$ :

a) Number of payment transactions;

b) Number of units that will provide financial services;

c) Financial services for the socially vulnerable and low-income population.

Among the above parameters, three are particularly important for the CSR model: the number of PNUs, the number of households with specific services, and the number of services available from the total number of available services. These parameters will serve to evaluate VII. Figure 7 shows the evaluation of the CSR model based on the first parameter - the number of PNUs. Since three parameters for the seven CSR models have been defined, the participation of the first model according to the first parameter will be expressed in \% with the mark $P_{11}$, that is $P_{n m}$, where $n=1, \ldots, 7, m=1,2,3$, and can be presented by Formula 1:

$$
P_{n m}=\frac{b_{j}}{\sum_{j=1}^{7} b_{j}} \cdot 100
$$

The main goal is that $P_{7 m}$ weighs the maximum value and represents the number of PNUs that is viewed through 3 dimensions and 4 domains. It can be represented by Formula 2:

$$
\sum_{m=1}^{3} P_{7 m} \rightarrow M A X
$$

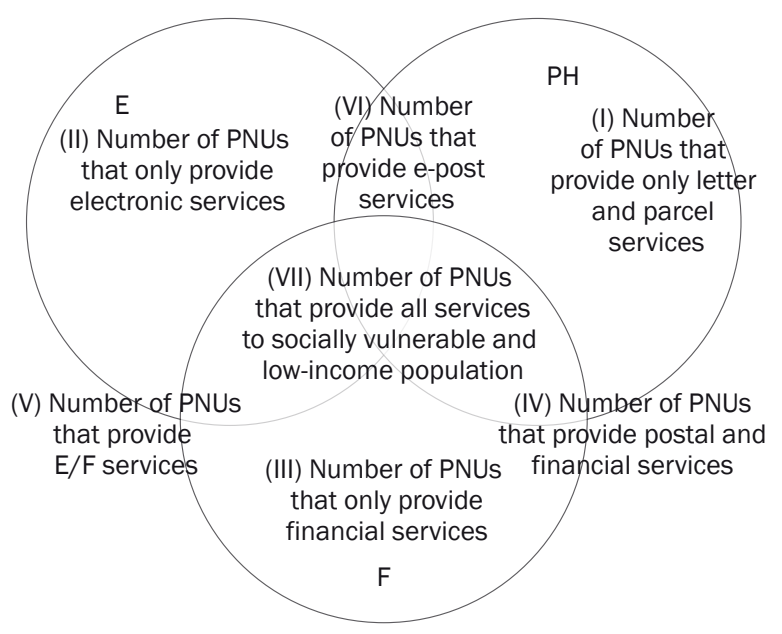

Figure 7 - Evaluation of the CSR model according to PNUs

Similarly, an evaluation would also be carried out based on another parameter (the number of households with available services), with the goal to have available as many households (including socially vulnerable households) and postal services (P72) as possible. The third parameter (the number of services 
from the total number of available services) is also important for the evaluation. Aiming to achieve the CSR model VII, as many postal, electronic, and financial services should be provided as possible (P73).

Evaluation will ensure the measurability of the proposed CSR model. In addition to the defined parameters, it is possible to observe some other system parameters according to which the CSR model VII will be evaluated, giving the model the features of dynamics, universality, and applicability.

\section{CONCLUSION}

The results presented in this paper have confirmed that it is possible to ensure socially responsible operation of the postal system through the development of the physical, electronic, and financial dimensions of the postal network. The measured CSR results have been presented through a case study of the public company Post of Serbia.

To optimally develop the physical dimension of the postal network, it was necessary to conduct an analysis of the postal service market, the UPS scope, and the existing postal network, as well as to provide the basic conditions for access to the postal network (access points, access pricing, defined quantities for all types of deliveries, UPS scope). The results of the development of the physical dimension of the postal network have shown that it is necessary to reduce the number of permanent postal network units for the provision of UPS, as well as to increase the locations for the provision of access to the postal network. In addition, conditions (access price and minimum quantity of deliveries per month) should be defined for the full liberalization of the market (abolition of the reserved area). The optimal level of development of the electronic network is considered by calculating the PES index to see the domain of the electronic services provided by the PPO of a country. The results of this analysis show that Serbia is $37^{\text {th }}$ with the PES index of -0.18 , and that further development of electronic commerce requires improvements to the telecommunication infrastructure. The optimal level of development of the financial network is considered based on the PPO's available resources in terms of providing financial services and on the introduction of new services that will provide social security and a better standard of the population.

The results obtained in this paper can be used to determine further directions of the development of the PPO's postal network. It can contribute to formulation of strategic activities that will influence faster liberalization of the postal market. In the end, this can create the necessary conditions for the opening of the Negotiation Chapter 3 (Right of establishment and freedom to provide services), necessary for the accession of the Republic of Serbia to the European Union.

\section{ACKNOWLEDGEMENT}

This research was supported by the Ministry of Education, Science and Technological Development of the Republic of Serbia, through Project TR 36040.

\section{Dr.sC. MARIJA UNTERBERGER ${ }^{1}$}

E-mail: marijaunterberger@gmail.com

Dip.ing.saob. PREDRAG VEŠOVIĆ 2

E-mail vesovic.pedja@gmail.com

Dr.sc. KATARINA MOSTARAC ${ }^{3}$

E-mail: kmostarac@fpz.hr Vanr.prof.dr. DRAGANA ŠARAC ${ }^{4}$

E-mail: dsarac@uns.ac.rs

Doc.dr.sc. SPASENIJA OŽEGOVIĆ5

E-mail: sozegovic@ptt.rs

${ }^{1}$ Saobraćajna škola „Pinki“ Novi Sad

Šumadijska 12a, 21000 Novi Sad, Srbija

2 TRANS LOGISTICS AG, Međunarodni transport i špedicija Bul. Arsenija Čarnojevića 130, 11070 Novi Beograd, Srbija

${ }^{3}$ Sveučilište u Zagrebu, Fakultet prometnih znanosti

Vukelićeva 4, 10000 Zagreb, Hrvatska

${ }^{4}$ Univerzitet u Novom Sadu, Fakultet tehničkih nauka

Trg Dositeja Obradovića 6, 21000 Novi Sad, Srbija

${ }^{5}$ Univerzitet Privredna akademija u Novom Sadu

Fakultet za primenjeni menadžment, ekonomije i finansije Jevrejska 24, 11000 Beograd, Srbija

\section{TRODIMENZIONALNI MODEL DRUŠTVENO ODGOVOR- NOG POSLOVANJA OPERATORA POŠTANSKE USLUGE}

\section{REZIME}

U ovom radu je pojam "Društveno odgovornog poslovanja" (DOP) prvi put prikazan na osnovu postojeće piramide, koja definiše DOP kao skup ekonomskih, pravnih, etičkih i filantropskih aktivnosti. Zatim je izvršeno dimenzionisanje modela društveno odgovornog poslovanja u poštanskom sistemu, pri čemu je definisano sedam kategorija DOP modela. Samo jedna kategorija (od sedam) predstavlja skup sve četiri aktivnosti definisane postojećom piramidom. Na osnovu toga razvijen je novi model društveno odgovornog poslovanja u poštanskom sistemu, koji se vidi kroz razvoj tri dimenzije poštanske mreže: fizičke, elektronske i finansijske. Osnovni cilj rada je definisanje takvog modela društveno odgovornog poslovanja koji će obezbediti ekonomski, društveni i ekološki razvoj poštanskog tržišta, sinergijskim delovanjem sve tri dimenzije poštanske mreže. Izvršena je analiza postojećeg stanja tržišta poštanskih us/uga, a zatim je određen nivo budućeg razvoja poštanske mreže. Evaluacijom ili sistematičnom i objektivnom procenom DOP modela, na osnovu utvrđenih parametara, dokazana je merljivost modela. Rad razmatra slučaj Javnog poštanskog operatora (JPO) u Republici Srbiji (RS).

\section{KLUUČNE REČI}

društveno odgovorno poslovanje; poštanska mreža; evaluacija; sinergija; poštansko tržište;

\section{REFERENCES}

[1] European Commission. Corporate Social Responsibility. National Public Policies in the European Union 
Compendium; 2014.

[2] Hopkins M. What is corporate social responsibility all about? Journal of Public Affairs. 2006;6(3-4): 298-306.

[3] Dahlsrud A. How corporate social responsibility is defined: an analysis of 37 definitions? Corporate Social Responsibility and Environmental Management. 2006;15(1): 1-13.

[4] International Organization for Standardization. International Standard ISO 26000; 2010.

[5] Caroll AB. The Pyramid of Corporate Social Responsibility: Toward the Moral Management of Organizational Stakeholders. Bussiness Horizons. 1991;34 (4): 39-48.

[6] Chandler D. Corporate Social Responsibility: A Strategic Perspective, Business Expert Press, New York; 2015.

[7] Higgs G, Langford M. Investigating the Validity of Rural-Urban Distinctions in the Impacts of Changing Service Provision: The Example of Postal Service Reconfiguration in Wales. Geoforum. 2013;47: 53-64.

[8] Langford M, Higgs G. Accessibility and Public Service Provision: Evaluating the Impacts of the Post Office Network Change Programme in the UK. Transactions of the Institute of British Geographers. New Series. 2010;35(4): 585-601. Available from: http://dx.doi. org/10.1111/j.1475-5661.2010.00394.x [Accessed Aug 6, 2017].

[9] European Postal Services and Social Responsibilities. CSR Europe, Corporate Citizenship Company, 2001. Available from: http://corporate-citizenship.com/ wp-content/uploads/post-offices.pdf [Accessed Aug $18,2017]$

[10] Lee J-H, Moon I. A Hybrid Hub-and-Spoke Postal Logistics Network with Realistic Restrictions: A Case Study of Korea Post. Expert Systems with Applications. 2014;41(11): 5509-5519.

[11] DIRECTIVE 1997/67/EC of the European Parliament and of the Council; 1997.

[12] Universal Postal Union, Decisions of the 2012 Doha Congress Final texts of the Acts signed at Doha and of the Decisions other than those amending the Acts. Berne: International Bureau of the Universal Postal Union; 2013.

[13] Schwartz S, Carroll B. Corporate social responsibility: A three-domain approach. Business Ethics Quarterly. 2003;13(4): 503-530.

[14] Stojanović-Višić B. Prilog metodologiji istraživanja stavova korisnika Pošte Srbije o društveno odgovor- nom poslovanju. Tehnika. 2016;66(4): 607-612.

[15] DIRECTIVE 2002/39/EC of the European Parliament and of the Council; 2002.

[16] DIRECTIVE 2008/6/EC of the European Parliament and of the Council; 2008.

[17] Ožegović S, Šarac D. Exploring the possibilities of application of the modified multiphase strategic model for key account management in postal services. African Journal of Business Management. 2012;14(6): 4964-4973.

[18] European Commission. Financial Services Provision and Prevention of Financial Exclusion. European Commission. Brussels; 2008.

[19] Ansón J, Bialot J. Financial inclusion, postal banking and the future postal economic model. In: Development strategies for the postal sector: an economic perspective. Universal Postal Union; 2014. p. 146-169.

[20] The World Bank. Financial inclusion strategies Reference framework. Washington; 2007.

[21] Universal Postal Union. Measuring postal e-services development: A global perspective. Berne, Switzerland: UPU; 2012.

[22] Šarac D, Kopić M, Mostarac K, Kujačić M, Jovanović B. Application of Set Covering Location Problem for Organizing the Public Postal Network. Promet - Traffic \& Transportation. 2016;28(4): 403-413.

[23] Mostarac K. Određivanje dostupnosti univerzalne usluge u poštanskom sustavu primjenom kriterija prometne povezanosti. PhD thesis. Sveučilište u Zagrebu, Fakultet prometnih znanosti; 2017.

[24] Unterberger M. Razvoj modela pristupa poštanskoj mreži. PhD thesis. Univerzitet u Novom Sadu, Fakultet tehničkih nauka; 2016.

[25] Lisec A, Rosi B, Kavran Z. Holistic Thinking Aproach: Case Study of Post Network in Slovenia. Promet - Traffic \& Transportation. 2008;20(2): 79-86.

[26] Dupljanin Đ, Kujačić M, Šarac D. Menadžment elektronskim servisima poštanskog sistema Srbije upotrebom benčmarking indeksa. Tehnika. 2014;64(3): 529-533.

[27] Šarac D, Marković M, Rogić B. Postal and financial inclusion. Proceedings of the $14^{\text {th }}$ International Symposium SymOrg, Faculty of Organizational Sciences, 6-10 June 2014, Zlatibor, Serbia; 2014. p. 715-721. 